\title{
Correction: dysregulation of matricellular proteins is an early signature of pathology in laminin- deficient muscular dystrophy
}

Thomas Mehuron*, Ajay Kumar, Lina Duarte, Jenny Yamauchi, Anthony Accorsi and Mahasweta Girgenrath

\section{Correction}

After publication of this work [1], we noted that while we were initially going to include muscle function tests in this study, as our manuscript evolved and we decided to include earlier time points for characterization, we decided to remove it because pups younger than 2 weeks cannot be measured. While we removed this from the results, we missed retracting them from the methods section of the abstract. Therefore, the methods section of the abstract should instead read:

\section{Methods}

We sought out to examine the dysregulation of various pathways throughout early development (postnatal weeks 1-4) in the DyW mouse, the most commonly used mouse model of laminin-deficient muscular dystrophy. Gene (qRT-PCR) and protein levels (western blot, ELISA) as well as histology (H\&E, picrosirius red staining) and immunohistochemistry (fibronectin, TUNEL assay) were used to assess dysregulation of matricellular proteins.

Received: 18 September 2014 Accepted: 18 September 2014

Published: 2 October 2014

\section{References}

1. Mehuron T, Kumar A, Duarte L, Yamauchi J, Accorsi A, Girgenrath M:

Dysregulation of matricellular proteins is an early signature of pathology

in laminin-deficient muscular dystrophy. Skeletal Muscle 2014, 4:14.

* Correspondence: tmehuron@bu.edu

Department of Health Sciences, Boston University, 635 Commonwealth Avenue, Boston, MA 02215, USA

Submit your next manuscript to BioMed Central and take full advantage of:

- Convenient online submission

- Thorough peer review

- No space constraints or color figure charges

- Immediate publication on acceptance

- Inclusion in PubMed, CAS, Scopus and Google Scholar

- Research which is freely available for redistribution

Submit your manuscript at www.biomedcentral.com/submit
Ciomed Central

\section{() Biomed Central}

